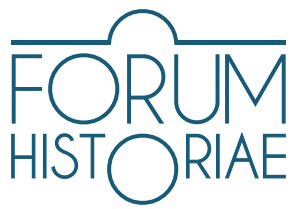

\title{
Self-publishing as a Surrealist Strategy: The Samizdat Catalogues of the Surrealist Group in Czechoslovakia
}

\author{
Kristin Watterott
}

\begin{abstract}
WATTEROTT, Kristin: Self-publishing as a Surrealist Strategy: The Samizdat Catalogues of the Surrealist Group in Czechoslovakia.

During the period of so-called normalization in the former Czechoslovakia, the restrictive cultural policy ousted numerous oppositional artists, theoreticians, and writers from the public cultural sphere through bans on exhibitions and publications. As a consequence, the affected individuals developed their own means of enabling creative, scientific, and literary work beyond censorship. A key medium for the realization of officially banned texts, studies, and projects was illegal and clandestine self-publishing, also called "samizdat".

This article discusses the phenomenon of samizdat using the example of the self-produced collections of the Surrealistická skupina v Československu. In the 1980s, the community created two (fictitious) exhibition catalogues, Sféra snu (1983) and Proměny humoru (1984), which presented the individual and collective surrealist activities with images, quotations, and written descriptions. However, the editions were not only a media of documentation to reconstruct surrealist practice. They were at the same time a creative way to exhibit their content in its own specific artistic forms and theories of art. In this paper, I explore the unacknowledged dual-function of the '70s and '80s Czech surrealist samizdat as both an archival technique and a work of art. I investigate the function of these volumes for group artistic praxis and how it reflects creative production under the social conditions of the time.
\end{abstract}

Keywords: samizdat, Czech Surrealism, self-publishing, Surrealist Group in Czechoslovakia, exhibition catalogue, communism, normalization

DOI: https://doi.org/10.31577/forhist.2020.14.2.2

$\mathrm{T}$ The Czech Surrealist Group was founded in $1934 .{ }^{1}$ Despite external influences that disrupted the network for some time and led to shifts in the structure and self-understanding of the collective, over 80 years later a surrealist community still exists in Czech Republic which follows the idea of uniting the practice of art and life. ${ }^{2}$

However, the 1970 s and 1980s marked a specific period for the group. ${ }^{3}$ With the beginning of so-called "normalization" after the violent end of the Prague

1 Skupina surrealistů $v \check{C} S R$ (Group of Surrealists in Czechoslovakia) was founded officially with the manifesto Surrealismus v ČSR (Surrealism in ČSR) in March 1934. In the 1970s the group renamed itself to Surrealistická skupina v Ceskoslovensku. Surrealismus v ČSR. In Zvěrokruh 1; Zvěrokruh 2; Surrealismus v ČSR; Mezinárodní bulletin surrealismu; Surrealismus. Prague : Torst, 2004, pp. 115-118. Author's note: all quotations are in the original published form.

2 For the history of the development of the surrealist community and its manifestations, see the study: TIPPNER, Anja. Die permanente Avantgarde? Surrealismus in Prag. Cologne : Böhlau, 2006. For the early years: BYDŽOVSKÁ, Lenka - SRP, Karel (ed.) Český surrealismus 1929-1953. Prague : Argo 1996.

3 It must be mentioned that the Surrealistická skupina $v$ Československu was not the only circle of surrealist protagonists in Czechoslovakia. However, when naming the surrealists, the paper is referring to 
Spring, the communist regime expelled the surrealists from the public sphere of art and culture. ${ }^{4}$ In the course of the restorative cultural policy, their works were classified as "cosmopolitan." The government declared the community to be the "Trojan horse of anticommunism". ${ }^{5}$ Surrealist editions disappeared from Czech publishing programmes and the group received a collective exhibition ban. Surrealist practice was considered anti-government and was officially prohibited. ${ }^{6}$

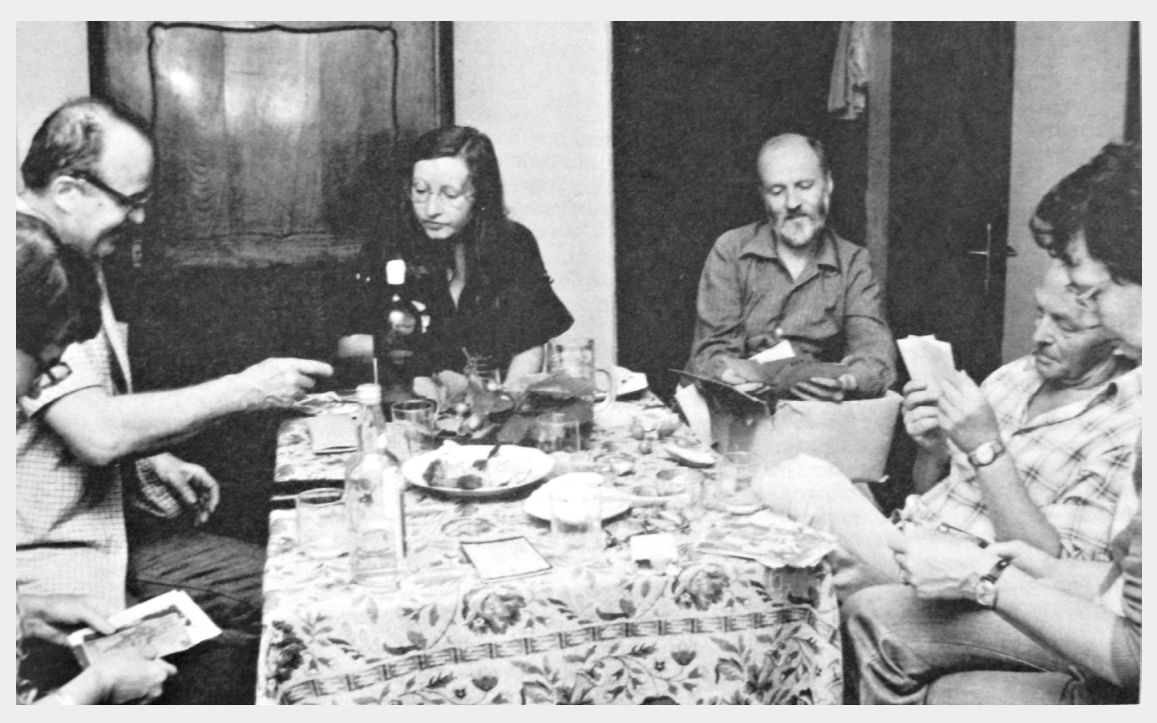

Figure 1. Meeting in the flat of Jan Švankmajer, 1973: from left to right: D. Marenčinová, A. Marenčin, E. Švankmajerová, J. Švankmajer, V. Effenberger, E. Effenbergerová. In: Analogon. Surrealismus - Psychoanalýza - Antropologie - Příčné Vědy. Z dějin československého surrealismu 1968-1989, 2004, No. 41/42, p.29.

From this point onwards, meetings, artistic exchanges, and collective interaction took place in private, for example in the apartments and studios of the members. ${ }^{7}$ With the new circumstances, the creative expression, presence in public, and forms of distribution of the surrealist works changed. Internally, the community devoted itself to experimental actions, such as surrealist games, internal surveys, and collective objects. ${ }^{8}$ Their activities pursued concrete aims. The focus was not on the production of a work of art, but the exploration of the creative process itself, with all its correlations. As a result of surrealist studies, thematic ensembles were created, for example on the phenomena of dreams, fear, or eroticism. In addition to collaborative projects, the collections contained theoretical texts and individual works by the members. ${ }^{9}$ The contributions were recorded

that specific group or its members.

4 At the same time, it must be emphasized that some surrealist projects could not be realized even before 1970 due to political sanctions.

5 "Surrealismus jako trojský kůn̆ antikomunismu" See DVORSKÝ, Stanislav - DRYJE, František - STEJSKAL, Martin (ed.) Surrealistická východiska (1948-1989): Odklony, Návraty, Přesahy. Znamení zvěrokruhu, Okruh pěti Objektů, UDS, Surrealistická skupina v Československu. Praha : Společnost Karla Teiga 2011, p. 51.

6 The restriction applied to group practice and to some projects of the members. Nevertheless, various members of the community were still able to realise individual exhibition projects.

7 DRYJE, František. Editorial: 1968-1975. In Analogon. Surrealismus - Psychoanalýza - Antropologie Př́ćné Vědy. Z dějin československého surrealismu 1968 - 1989, 2004, No. 41/42, p. ii.

8 Collective objects are works of everyday items or collages that the Surrealists designed together to form a theme. In the case of the surrealist game, the community devoted itself to an interactive project similar to the concept of parlour games. The group's internal surveys are theme-based interviews on phenomena such as dreams, eroticism, and fear, and served to determine the members' positions.

9 SURREALISTICKÁ SKUPINA V ČESKOSLOVENSKU. Úvod. In ŠVANKMAJER, Jan (ed.) Otevřená hra. Mezi surrealismem a surracionalismem. Antologie tvorby Surrealistické skupiny v Československu 1969-1979. Geneva (Prague) : Le La, 1979, p. 5. 
by the community in independently produced, privately circulated documents, so-called samizdat publications. ${ }^{10}$

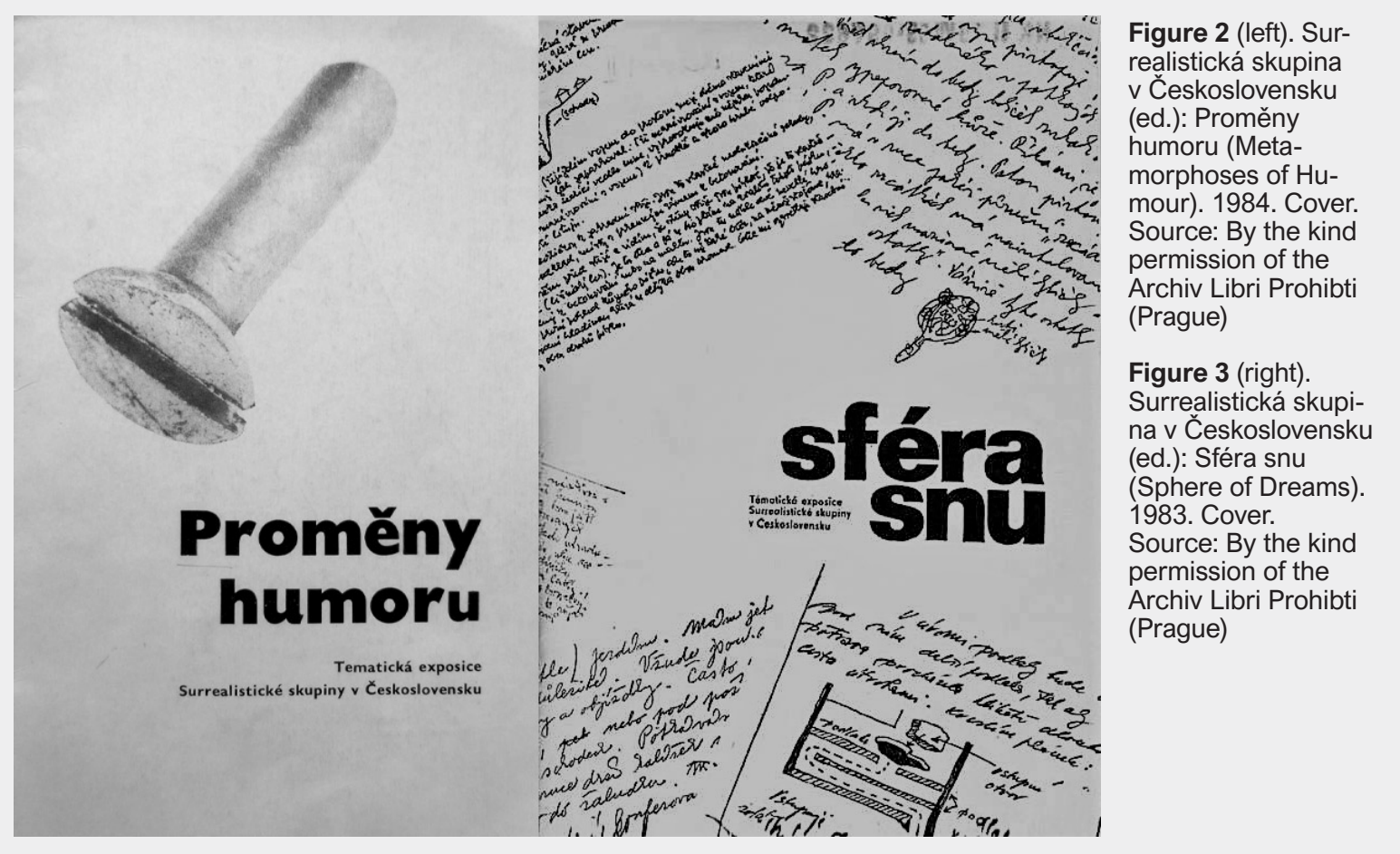

In 20 years of public isolation, six collective samizdat projects were created by the group, including two self-published catalogues, Sféra snu (Sphere of Dream, 1983) and Proměny humoru (Transformations of Humour, 1984). ${ }^{11}$ Both editions contain the subtitle Tématická exposice Surrealistické skupiny v Československu (Thematic exposition of the Surrealist Group in Czechoslovakia), which classifies the activities as part of an installation that is seemingly taking place..$^{12}$ Nevertheless, the two issues represent a specific form of exhibition catalogue: they were not exposed to the contemporary public at large but appear instead as actions that record the surrealistic activities of the community that took place in the private sphere. ${ }^{13}$ At the same time, they express various forms of creative self-staging and artistic positions on the basis of their programmatic, organisational,

10 The word and the term samizdat refer to a kind of "copyright" note of the poet Nikolai Glazkov from the 1940s. Publishers of that time did not print his works, so he noted on his volumes of poetry the reference samsebjaizdat (self-published). EICHWEDE, Wolfgang. Archipel Samizdat. In EICHWEDE, Wolfgang (ed.) Samizdat. Alternative Kultur in Zentral- und Osteuropa: Die 60er bis 80er Jahre. Bremen : Edition Temmen, 2000, p. 8.

11 Collective projects refer to activities in which the group and its members are present in terms of content and which were produced by the majority of its protagonists. The mentioned editions are part of the series $L e L a$, in which the following works were also created: the anthologies Otevřená hra (Open Game) and Opak zrcadla (The Reverse of a Mirror) as well as the journal Gambra. The title Le La refers to the surrealist circle of the same name in Switzerland, with which the members of the Prague group collaborated. For this reason, the reference to Geneva as a (fictional) production place is also found on the volumes. Another joint edition was Studijní materiály a dokumentace (Study materials and documentation).

12 See Sféra snu. Tématická exposice Surrealistické skupiny v Československu. Geneva (Prague) : Le La, 1983. Proměny humoru. Tématická exposice Surrealistické skupiny v Československu. Geneva (Prague) : Le La, 1984.

13 Note: The project Sféra snu was nevertheless planned as an exhibition project, but it never took place in a public space. 
and productive arrangement, as well as their form of documentary implementation. Hence, surrealist samizdat is also the result of a common artistic practice and can be read as an autonomous creative strategy that reflects the principles of surrealist art appreciation.

This paper examines the unrecognized double function of Czech surrealist samizdats, both as an archiving technique and as independent artistic projects. Following a description of the editions, the conceptual structure and mediation strategies of surrealist activities are to be determined through an analysis of examples. Based on the results, conclusions should be drawn about the specific form of art production, which had different functions for the community.

\section{The surrealistic catalogues and their presentation of the material}

The catalogue projects Sphere of Dream and Transformations of Humour were created in the mid-1980s and appear in A5 format in black and white print with over 30 pages. The production was done internally, with all of the work steps remaining within the sphere of activity of the community. The following were involved in their realization: Karol Baron, František Dryje, Vratislav Effenberger, Jiří Koubek, Albert Marenčin, Emila Medková, Alena Nádvorníková, Martin Stejskal, Ludvík Šváb, Jan Švankmajer, and Eva Švankmajerová. ${ }^{14}$

During their material creation, the members first produced a template of the individual pages in typesetting using a letterpress, which was cut by hand and put in the correct order. With the help of a printer, the created pages were photographed and transferred onto metal templates. The reproduction was done by means of small offset printers on special offset paper. The pages were bound and wrapped in a cover. The volumes ran between 100 and 300 copies in their circulation. ${ }^{15}$

The collective catalogue projects are thematically structured in their content. They demonstrate surrealist activities on the phenomena of humour and dreams, respectively, which took place in the 1970s and 1980s. The volumes present works on various media; they compile them in a collection and record them with images and text. In addition to the group activities in the form of surrealist games, individual contributions, such as theoretical essays, poetic texts, notes and commentaries, as well as film scripts, dream descriptions and prose, are included. The field of visual works ranges from photography, collages and graphics to drawings, images of object art and painting.

In its systematization of the material, the community developed thematic categories. Sphere of Dream is divided into three sections: Mezi spánkem a bděním (Between Sleep and Waking), Vnitřním zrakem (Through Inner Vision) and Noční návštěvy (Night Visits). The catalogue Transformations of Humour covers more than ten thematic areas, including Humor a hra (Humour and a Game),

14 Cooperation reconstructed from the contributions of the catalogues. Note: Koubek is not named in the Transformation of Humour project.

15 KOŠNAROVÁ, Veronika. LE LA. In PŘIBÁŇ, Michal (ed.) Český literární samizdat 1949 - 1989: Edice, časopisy, sborníky. Prague : Academia, 2018, p. 303. 
Snový humor (Dreamy Humour), Humor a erotika (Humour and Eroticism), Humor a strach (Humour and Fear).

The individual sections are characterized in their conception by media diversity: Theory merges with visual art and poetry. The individual parts are not arranged according to actor, form of expression or chronology of the creation. Moreover, its diversity is also reflected in the presence of the members. The categories are formed by contributions of different authors, not by individual members' works. The thematic focus of each section is established only through interaction.

The catalogues have an equal ratio of images and texts, which are not presented separately. The visual works link with the written works on one page, side by side. Yet the picture and text are not by the same author. In the material presentation of surrealist practice, the contributions are characterized by extracts. Some of the works are signed with the tag Fragmenty (Fragments). These concern theoretical essays, poetic writings and creative works. The extent and context of the "original version" remains open. In addition, the community provides only limited information about its work. The visual images are titled with author, title and year, but in some cases only the name of the creator is noted. Information about dimensions, material, colour and location are not provided. Further, no explanations of the content or detailed references to the author's contribution are included.

At the same time, the printed format in the catalogue does not indicate the real dimensions of the works. Photographs, paintings, collages and object art do not appear in any unified size pattern or in sizes relative to each other. No dimensional references can be deduced from the illustrations. The text contributions mainly present only the author, title and year. Only a few writings are noted without title or year.

\section{Transformations of Humour - documentary practice}

In its depictive element, the surrealist catalogue is a means of preserving thoughts, concepts, writings, and records of artistic works. In this regard, it does not only list the surrealistic material but constructs content by way of creation and combination. The reappraisal of the surrealist work is initially subject to design principles and to the technical possibilities inherent to the book object. The print format allows artistic works to appear in a different reality: they lack physicality, scale, and colourfulness, as well as forms, movements, and sound effects, due to the transfer of media. ${ }^{16}$ In the course of this, the modifications in media can formulate expanded elements, perspectives, and statements and also create new modes of perception. In Transformations of Humour this can be seen in different media, such as film, photography, and object art.

16 BOSSE, Dagmar. Souvenir, Dokument und Substitut. Die Abbildung im Ausstellungskatalog. In BOSSE, Dagmar - GLASMEIER, Michael - PRUS, Agnes (ed.) Der Ausstellungskatalog. Beiträge zur Geschichte und Theorie. Cologne : Salon Verlag, 2004, p. 38. 

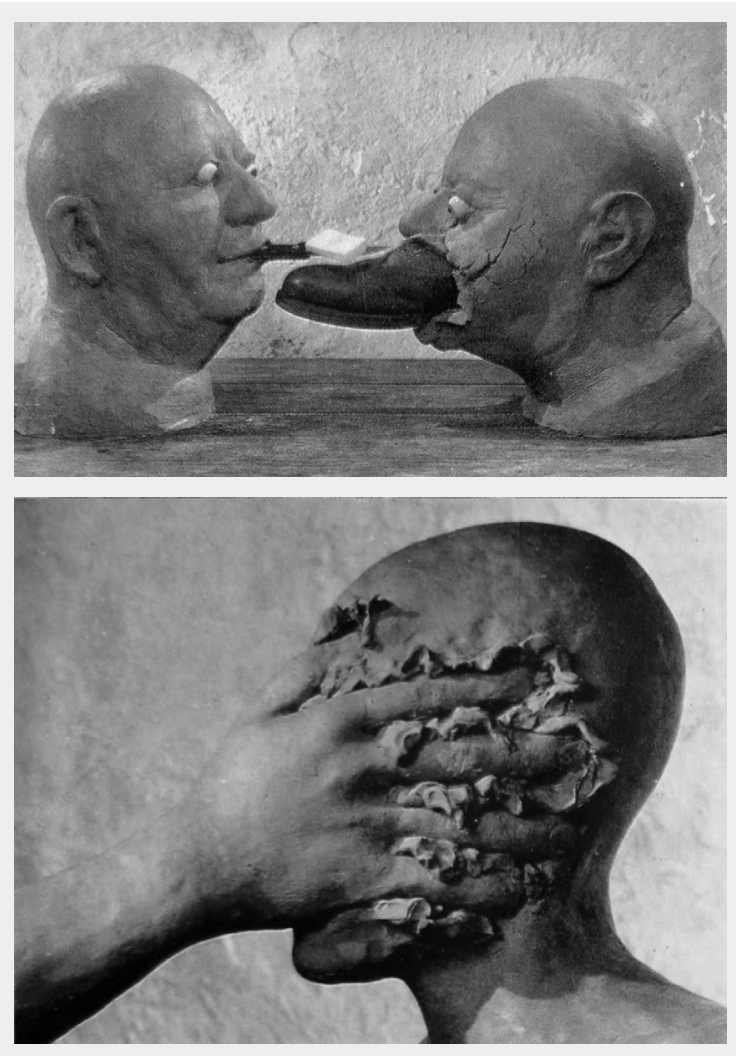

Figure 4. J. Švankmajer: Možnosti dialogu (Dimensions of Dialogue, 1982)/ film. In: Surrealistická skupina v Československu (ed.):

Proměny humoru (Metamorphoses of Humour). 1984, p. 17. Source: By the kind permission of the Archiv Libri Prohibti (Prague).

Figure 5. J. Švankmajer: Možnosti dialogu (Dimensions of Dialogue, 1982)/ film

In: Surrealistická skupina v Československu (ed.):

Proměny humoru (Metamorphoses of Humour). 1984, p. 18.

Source: By the kind permission of the Archiv Libri Prohibti (Prague).
Švankmajer's short film Možnosti dialogu (Dimensions of Dialogue, 1982) is presented in two photographic sequences. ${ }^{17}$ The contribution shows a visual excerpt of Švankmajer's work, which in its presentation is subject to a double transfer of media. In the fragmentation of the photographic images, it is on the one hand returned to the original format of the individual picture of which it consists, and on the other hand, it is reproduced again in the catalogue as a print.

The medial change of the work Dimensions of Dialogue - from the moving image to the still image - leads to a different reception of its technical and contentrelated elements. Formal data, such as the length of film, sound, and genre, as well as design features in the form of the subject, theme, and action, cannot be registered. Only the title of the picture refers to the film medium. The extracts of the image sequences modify the perception: the protagonists and their characteristics are at the centre of view. Thus, the focus shifts from the plot of the action to the presence of the characters.

Photographic works create their own modes of perception in transfer due to their media-specific characteristics. In contrast to film, photography appears in the catalogue in its original form as a photographic image, for example, the study Šebestián (Sebastian, 1977) by Med-

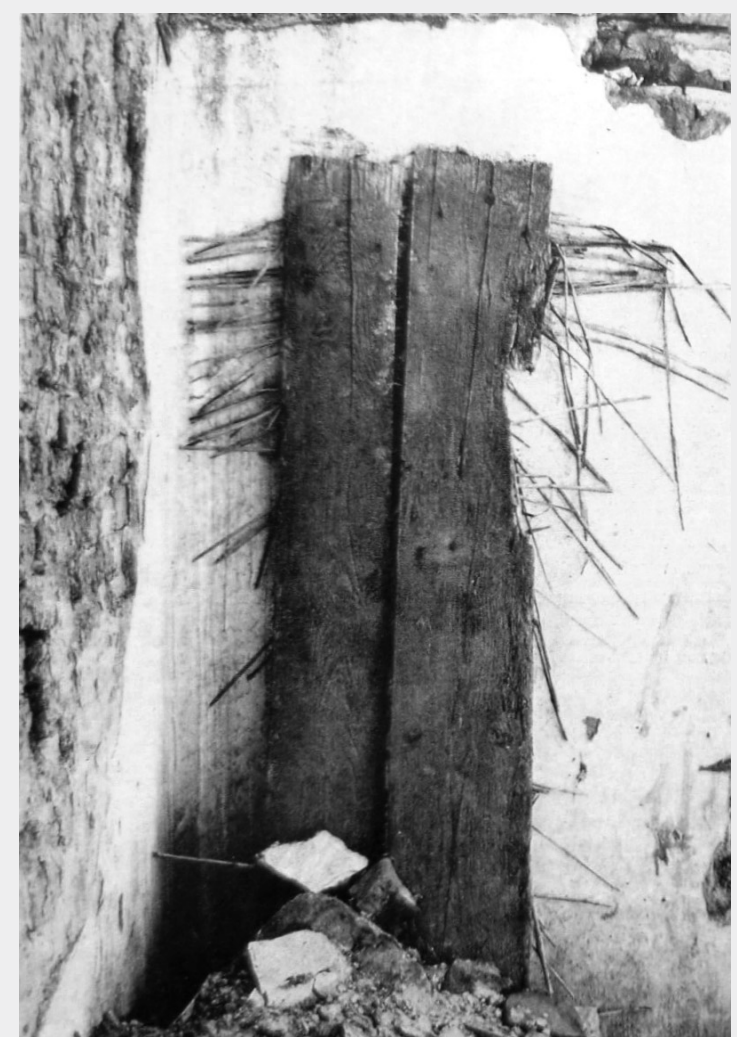

Figure 6. E. Medková: Šebestián (Sebastian, 1977)/ photograph. In: Surrealistická skupina v Československu (ed.): Proměny humoru (Metamorphoses of Humour). 1984, p. 12. Source: By the kind permission of the Archiv Libri Prohibti (Prague). ková. ${ }^{18}$ The black-and-white photograph 
shows and interprets natural materials of the environment: in front of a stone wall with loosened plaster a wooden board is leaning, with straw stalks protruding from its sides.

Samizdat captures the photograph Sebastian in a changed form. With regard to the first version, the work is presented in a print on a reduced scale. ${ }^{19}$ In its transfer, the light-dark effects, paper quality, and excerpt of the work are changed. In its reproduction, photography appears as a reinterpretation of the surrealistic perception of the surroundings, as other ways of seeing arise. New views also open up through changed contexts. The thematic location in Transformations of Humour refers to the humorous elements in Medková's work, which can be experienced in their cohesive observation through their integration into the catalogue project.

The change of media not only produces an altered experience of the content, formal, and contextual elements of the surrealist works but also plays with forms of appropriation. Švankmajer's tactile poem Prázdniny (Holidays, 1983) employs the sense of touch.$^{20}$ His object consists of hand gestures pressed into clay. According to the author, his poetry takes place in the inner eye, by stimulating the recipient's imagination through touch. ${ }^{21}$ Individual word descriptions are attributed to them. ${ }^{22}$

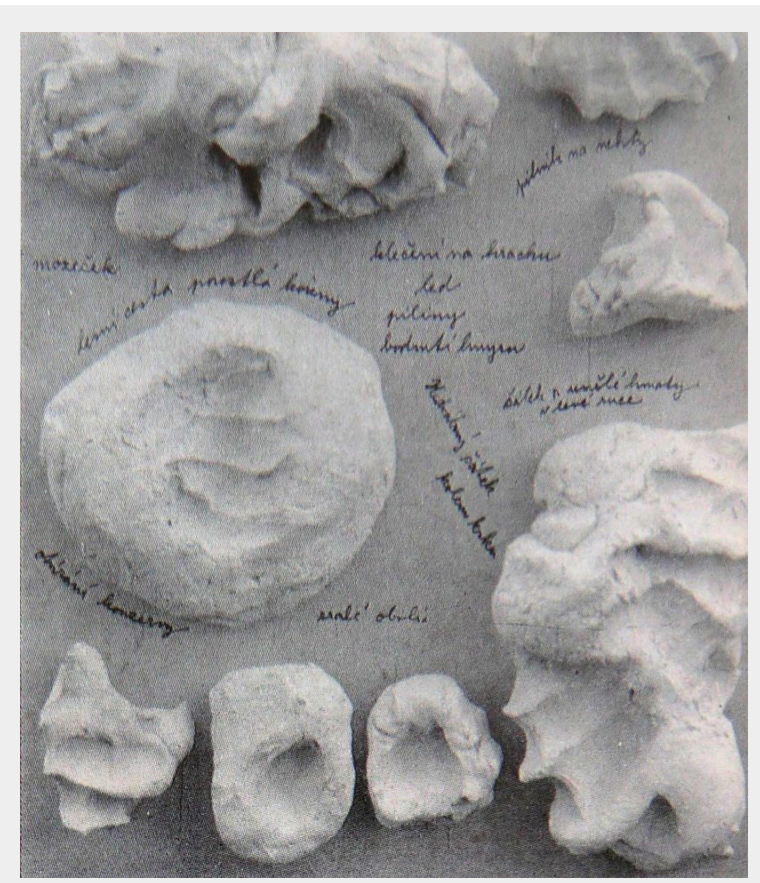

Figure 7: J. Švankmajer: Prázdniny (Holidays, 1983)/ tactile poem. In: Surrealistická skupina v Československu (ed.): Proměny humoru (Metamorphoses of Humour). 1984, p. 5. Source: By the kind permission of the Archiv Libri Prohibti (Prague).
In the photographic depiction in the catalogue, Švankmajer's poem can only be received visually. Nevertheless, the form of presentation may aim at individual experience. The viewer can see materials, forms and words that trigger familiar patterns of perception, e.g. the feeling of clay on the skin. The recipient can develop his own associations based on subjective recognition. The pictorial representation leads to a different form of reading than intended in the first work. Instead of stimulating the imagination by feeling, experiences are stimulated by seeing.

The dissolution of media-specific characteristics of the forms of expression caused by the change of media

19 The work is located in the Moravská galerie, Brno, Inventory number: MG 12323, $28.1 \mathrm{~cm} \mathrm{x} 38.2 \mathrm{~cm}$, paper, matt. Available online: http://sbirky.moravska-galerie.cz/dielo/CZE:MG.MG_12323

20 SVANKMAJER, Jan. Prázdniny (gestická báseň). In Proměny humoru. Geneva (Prague) : Le La, 1984, p. 5.

21 The recipient is forced to understand the poem not as an artefact, but as the emotions of the creator, which is directed to the mental imagination of the recipient. ŠVANKMAJER, Jan. Gestural Sculpture. In ŠVANKMAJER, Jan (ed.) Evašvankmajerjan: Anima Animus Animation, Between Film and Free Expression. Prague: Arbor vitae, 1997, p. 74.

22 For example: led (ice), mozeček (cerebellum), piliny (sawdust). 
creates an apparently uniform appearance of the visual works in the catalogue. Formal analogies arise in their recording and transfer into a two-dimensional medium. The different reproduction strategies stand side by side on an equal footing. In their altered presentation, they allow the Surrealist group to accentuate the elements essential to the project Transformations of Humour. Content, theme, and narratives are the focus of the recording. Medial properties, such as dimensions, colour application, and state of preservation, take a subordinate role - which becomes visible not least in the deprivation of data. Their reproduction enables a modified perception and the creation of new meaning. ${ }^{23}$

Due to their arrangements, the registered entries are given an extended construction of meaning in the form of their presentation in the catalogue. The intermedial combination of images and word art is the main characteristic of the Transformations of Humour. ${ }^{24}$

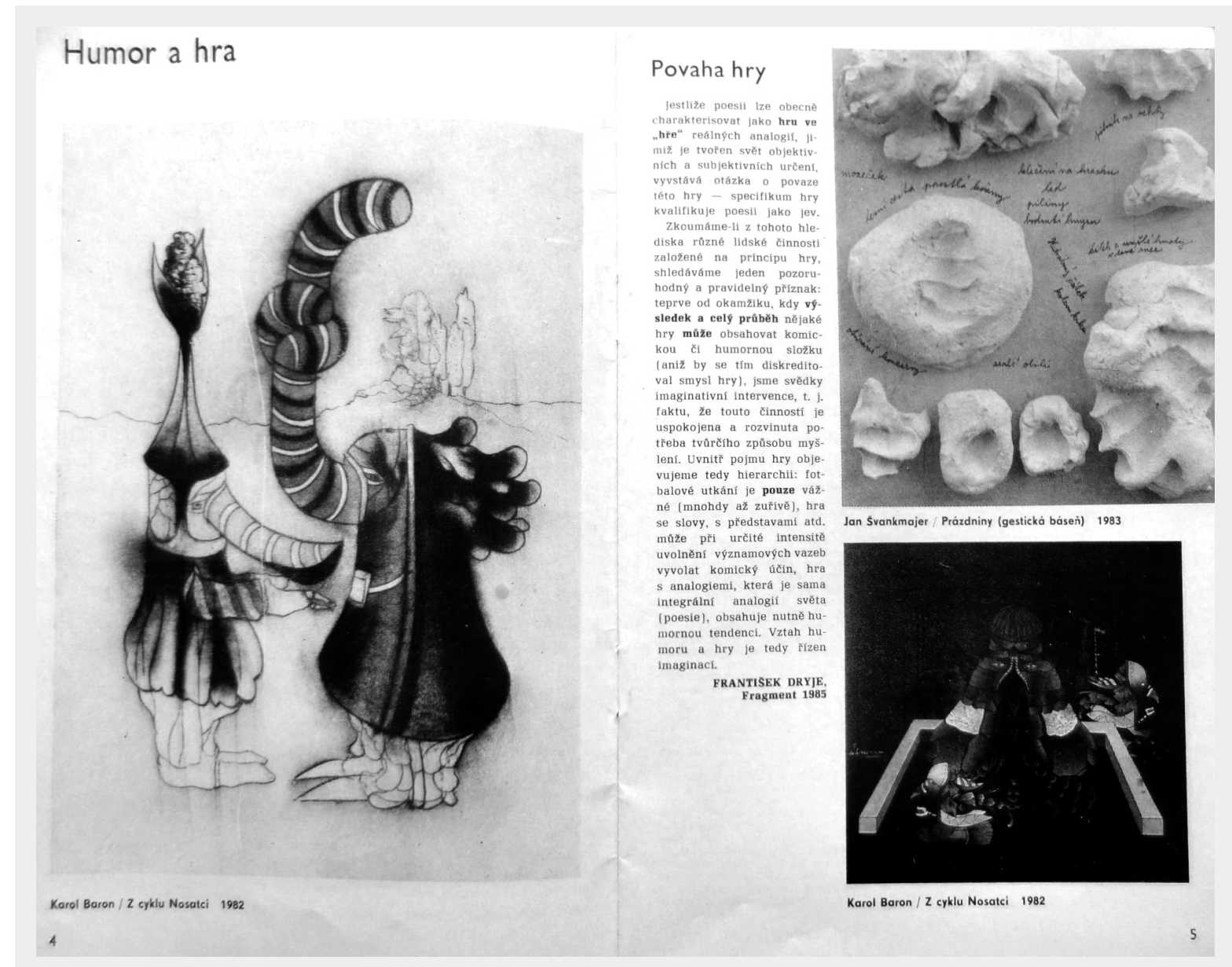

Figure 8: Categorie: Humor a hra (Humour and a Game). In: Surrealistická skupina v Československu (ed.): Proměny humoru (Metamorphoses of Humour). 1984, p.4/ 5. Source: By the kind permission of the Archiv Libri Prohibti (Prague).

23 GEIMER, Peter. The Art of Resurrection Malraux's Musée imaginaire. In CARAFFA, Costanza (ed.) Fotografie als Instrument und Medium der Kunstgeschichte. Berlin - München : Deutscher Kunstverlag, 2009, p. 78.

24 Intermediality refers to the combination and interference of different media and forms of expression within a frame of reference. RAJEWSKY, Irina O. Intermedialität. Munich : UTB, 2002, p. 13. 
In the systematization of the category Humour and a Game, the group depicts four different types of works. Two pictures by Baron from the cycle Nosatci (1982) are presented. ${ }^{25} \mathrm{His}$ visual contributions show fictional figures in grotesque landscapes, which carry the viewer into a poetic world. In their characteristic form they play with imaginative perception in a humorous way and bring the mysterious to life. ${ }^{26}$ Baron's works are complemented by Švankmajer's tactile poem Holidays and the text Povaha hry (The Character of the Game, 1985) by Dryje, presented as a fragment. Dryje's analytical explanations provide clarification of humorous elements in the game, which - as he emphasizes - are expressed through the implementation of imaginative processes. ${ }^{27}$

The chapter Humour and a Game is realized by linking all the contributions. Baron and Švankmajer's works transform Dryje's theoretical descriptions into a visual and creative form. Conversely, the creative works make the analytical explanations visually experienceable by playing with and opening up humorous emotions in the appropriation.

The creative works are not aesthetic elements; they are rather statements that complement one another. Even if the works can be viewed individually, it is the interplay of the media difference that constitutes the construct of the chapter's meaning and thus specifies the playful component of the humour and makes it accessible to experience. The documentary practice that is expressed in the catalogue not only fixes the surrealist activities but also makes altered access to the works possible in the form of its implementation.

\section{A specific challenge: the recording of ephemeral projects}

Besides the reappraisal of reconstructions of artistic, theoretical, and poetic works, the community is confronted with the task of recording ludic projects, which are determined by the characteristic of performativity. The form of the activities is characterized by an ephemeral, interactive, and experimental character. The practical implementation of the action is marked by situational, action-oriented, and transitory elements.

In the catalogue Transformations of Humour, under the category Surrealistická experimentace (Surrealistic Experimentation), the ephemeral project Jedním uchem dovnitr (One Ear In, 1984) appears. The surrealist game happened in February 1984 under the direction of Švankmajer. In addition to him, ten other members of the group took part: Baron, Dryje, Effenberger, Koubek, Marenčin, Medková, Nádvorníková, Stejskal, Šváb, and Švankmajerová. ${ }^{28}$

25 BARON, Karol. Z cyklu Nosatci. In Proměny humour. Geneva (Prague) : Le La, 1984, p. 4-5.

26 The works are also characterized by their variety of colours. Baron contrasts the mystical landscape with the imaginative beings in a humorous way through colourfulness. In the catalogue the works appear in black and white print. DRYJE, František. Úvodní slovo. Karol Baron - Rozhněvaný snivec. Available online: http://gej.vejr.cz/?page_id=8453.

27 DRYJE, František. Povaha hry. In Proměny humoru. Geneva (Prague) : Le La, 1984, p. 5.

28 Surrealistická experimentace. In Proměny humour. Geneva (Prague) : Le La, 1984, p. 29. 


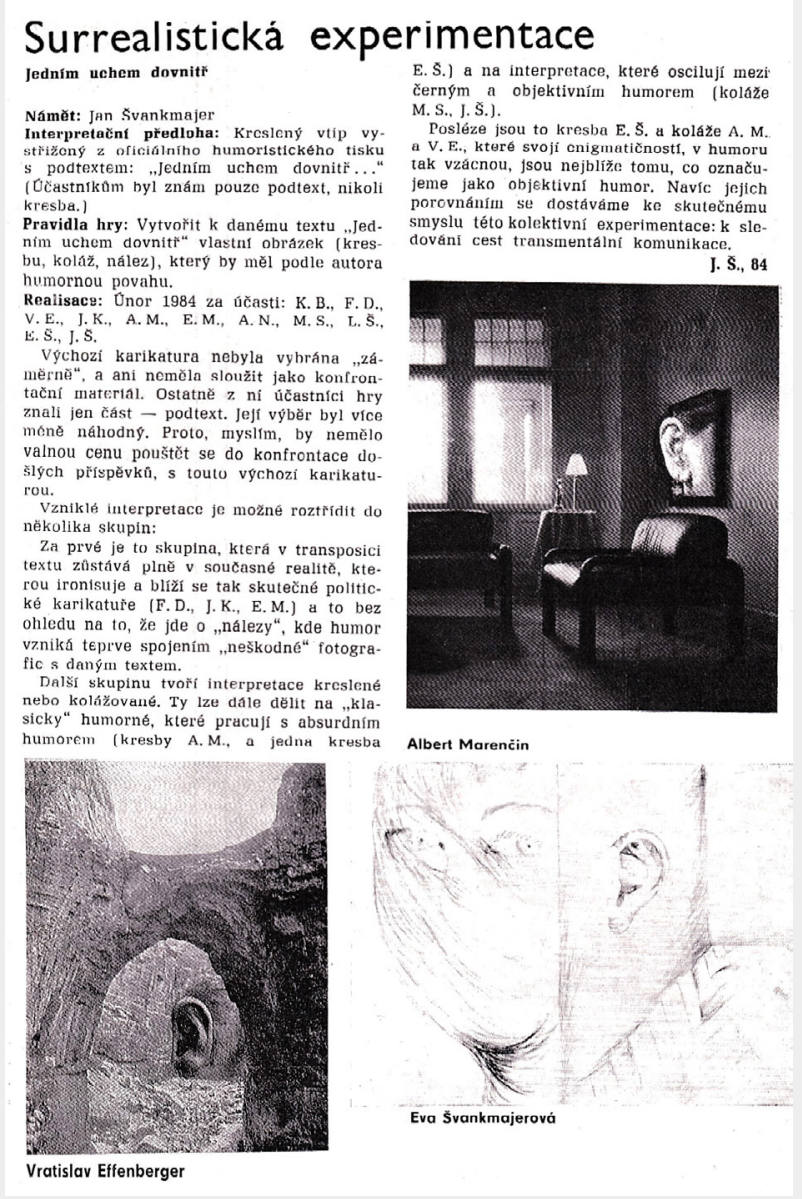

Figure 9: Surrealistická experimentace (Surrealistic Experimentation): Jedním uchem dovnitř (One Ear In, 1984)/ game In: Surrealistická skupina v Československu (ed.): Proměny humoru (Metamorphoses of Humour). 1984, p. 29. Source: By the kind permission of the Archiv Libri Prohibti (Prague)
The starting object of the activity was a drawing from the satirical magazine Dikobraz (Porcupine) with the title Jedním uchem dovnitr. ${ }^{29}$ Švankmajer only used the phrase "One ear in" as an element of play. ${ }^{30}$ The game concept required the members to create a humorous illustration of the subtext by the means of interpretative appropriation. The participants were familiar only with the phrase and not with the caricature. In the creative implementation, the choice of means of expression from drawing to painting to object art - was entirely up to the players. Once the task was realized according to the instructions, the act was evaluated. In the recording of personal contributions, the answers were noted, categorized, and classified. The aim of the analysis was to systematize the types of humour. ${ }^{31}$

In the catalogue the game One Ear In is recorded on one page. The community used written and visual material in the representation of the collective action. The presence took the form of a listing of the data: Name of the game, name of the game leader and rules, time of realization, registration of the participants, and the method. ${ }^{32}$ Švankmajer's evaluative commentary makes the aims and objectives of the action comprehensible.

In the form of its documentary recording, the presentation in the catalogue reveals itself to be a separate strategy for determining its performative character. The central element is the title of the section: Surrealistic Experimentation. It classifies the contribution as a project of interactive action.

29 The magazine Dikobraz appeared as a weekly satirical magazine between 1945 and 1989. The conception and content of the issues were subordinated to the political line of KSČ. Examples can be found online: https://dikobraz.cz/archiv.

30 Švankmajer calls the selected image kreslený vtip (a cartoon). See Jedním uchem dovnitř. In Analogon. Surrealismus - Psychoanalýza - Antropologie - Př́ćčné Vědy. Z dějin československého surrealismu 19681989, 2004, No. 41/42, p. 122.

31 Surrealistická experimentace. In Proměny humour. Geneva (Prague) : Le La, 1984, p. 29.

32 The initials of the players are listed alphabetically as follows K.B., F.D., V.E., J.K., A.M., E.M., A.N.,M.S., L.Š.,E.Š., J.Š. The game master (J.Š.) is also a participant. 


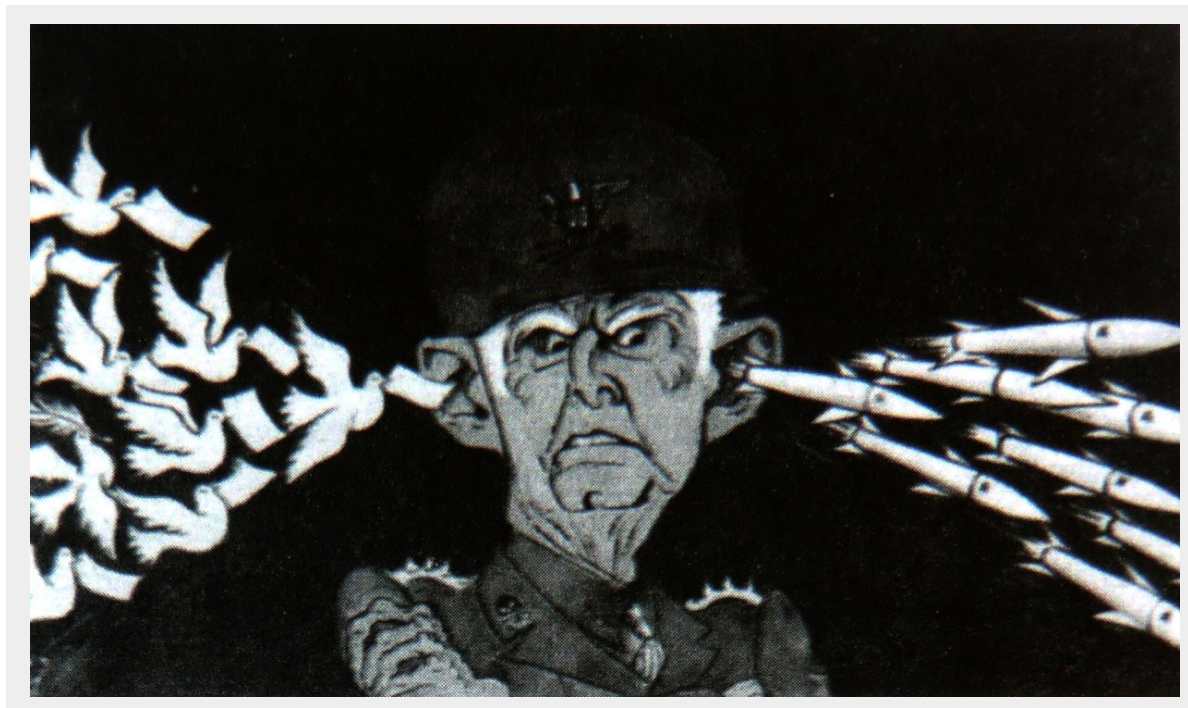

Figure 10: Game object with title Jedním uchem dovnitř from magazine Dikobraz In: Analogon. Surrealismus - Psychoanalýza - Antropologie - Příčné Vědy. Z dějin československého surrealismu 19681989, 2004, No. 41/42, p. 122.

The description of the game is chronological. Thus, the community determines the sequence of the stations: At the beginning, the data of the game is listed, which refers to the planning phase. By means of explanations of the rules and game elements and the naming of participants, the course of the playful interaction is recorded. The subsequent presentation of the reactions and the illustration of the creative answers make the results comprehensible.

The act of playing represents a temporary action. The form in which the group subsequently documents it dissolves the central feature of the ephemeral. ${ }^{33}$ The catalogue appears as a source of particular events which are retrospectively recordable and re-constructible. ${ }^{34}$ In this intention, the documentary presence reveals itself as a surrealist strategy. The game invites the reader to replay and repeat, as rules, game objects, and objectives can be received. ${ }^{35}$ The form of interaction and reaction is opened, as it lacks the surrealistic game instructions.

The principle of repetition is understood in surrealistic practice as a creative and epistemological process. ${ }^{36}$ Reproductive appropriation implies the interpretation of what has already happened. The old familiar is examined, questioned, and put to the test. The interpretive perception of the material in connection with one's own experience and subjective views leads to a new way of seeing and a modified order of existing. ${ }^{37}$ Associations are set free, which unfolds their creative potential in practical implementation.

In the realization, repetition also gains psychoanalytical significance. The process of repetition is based on the method of working through, which enables access to suppressed stimuli and encodings as expressed in dreams and imaginative phenomena. ${ }^{38}$ In the process, the repetitive self-reference creates the ever-same

33 TIPPNER, Anja. Die permanente Avantgarde? Surrealismus in Prag. Cologne : Böhlau, 2006, p. 185.

34 AUSLANDER, Philip. Zur Performativität der Performancedokumentation. In CLAUSEN, Barbara (ed.) After the Act. Die (Re)Produktion der Performancekunst. Nürnberg : Verlag für Moderne Kunst, 2006, p. 26.

35 TIPPNER 2006, p. 191.

36 TIPPNER 2006, p. 191.

37 TIPPNER 2006, p. 95 and 99.

38 This shows the relevance of the theory Remembering, Repeating and Working-Through of Sigmund 
in the field of the socially imaginary. The permanent reproduction dissolves mere perception and leads into irreality. ${ }^{39}$

According to the surrealist view, irrationality allows access to inspiration and the imaginative sphere. It opens the path to the perception of one's own self and the experience of true thoughts and feelings, as Nádvorníková defines in the text Surrealist Cognition: "It changes not only the world but also itself through the permanent activity that is the destruction of the static image of the world. It is a cognition that is a concrete act through which we change what we recognize and we change through such a cognition." ${ }^{\prime 4}$ This understanding expresses the surrealistic conviction that the reception of an artistic work is an active and creative principle. ${ }^{41}$ The collective project does not exclusively convey information but determines the process of perception as a creative act and a means of self-knowledge.

The process of "replay" is characterized by interactive elements. Reading becomes a participatory action, which maintains the performative character of the game. ${ }^{42}$ Reflection involves the viewer in the surrealistic project and makes him or her part of the work. ${ }^{43}$ In this way the boundaries between the two positions dissolve. The reader is both consumer and producer. ${ }^{44}$ This reflects a central concern of surrealist practice, as the community emphasizes: "...the author and the viewer are both interpreters or, to be more precise, from a surrealist activity is neither creative work or its consumptions, but COMMUNICATION." 45 The documentary recording of the game functions as a medium between mediation and communication. Surrealistic activity cannot only be received visually, but experienced with all senses and staged in its repetition. Anyone who interprets the game becomes an "artist".

This reflects the surrealistic view that authentic (creative) expression is not subject to any profession. ${ }^{46}$ Creativity is independent of rules, guidelines, and education. Thus, the surrealist understanding is also directed against the predetermined social, economic, and intellectual status of an artist. The community follows the opinion that "art will be made by all" ${ }^{47}$ It negates the attribution of being an artist as a professional phenomenon and is directed against an apparent aesthetic of genius based on talent, aptitude, and technical abilities. ${ }^{48}$

Freud. SCHWEPPENHÄUSER, Gerhard. Ästhetik. Philosophische Grundlagen und Schlüsselbegriffe. Frankfurt/Main : campus, 2007, p. 180.

39 SCHWEPPENHÄUSER 2007, pp. 181-182. TIPPNER 2006, p. 122.

40 See NÁDVORNÍKOVÁ, Alena. Surrealist Cognition. In Analogon. Surrealismus - Psychoanalýza - Antropologie - Př́ćné Vědy. Genius loci - imaginace prostoru, 2005, No. 44/45, pp. xiii-xiv.

41 TIPPNER 2006, p. 191.

42 TIPPNER 2006, p. 191.

43 GELDMACHER, Pamela. Re-Writing Avantgarde: Fortschritt, Utopie, Kollektiv und Partizipation in der Performance-Kunst. Bielefeld : transcript, 2015. p. 49.

44 CONVENTS, Ralf. Surrealistische Spiele: vom “Cadavre exquis" zum "Jeu de Marseille”. Frankfurt : Peter Lang, 1996, p. 1.

45 THE GROUP OF CZECH AND SLOVAK SURREALISTS. In DRYJE, František (ed.) Invention. Imagination. Interpretation. A Retrospective Exhibition of the Group of Czech and Slovak Surrealists. Swansea, 1998, p. 3.

46 Already André Breton claimed, "the absolute equality of all human beings in front of the unconscious". See CONVENTS 1996, p. 179.

47 See SVITÁK, Ivan. Windmills of Humanity: On Culture and Surrealism in the Manipulated World. Chicago : Charles H. Kerr Publishing Co., 2014, p. 121.

48 RECKWITZ, Andreas. Kreativität und soziale Praxis. Bielefeld : transcript, 2016, p. 191. 
Following the principle, the Surrealist group also adopts the dual position of consumer and producer in the realization of the ludic project. In implementing Švankmajer's rules of the game, the participants create artistic works based on the imaginative interpretation of the original object. The form of the subsequent evaluation opens up a further level of reception by classifying, categorizing, and documenting the creative works. ${ }^{49}$

The permanent role reversal and mutual transformation of the game elements from artistic design to creative interpretation to documentation - opens up a continuous communication process. The communicative exchange takes place not only among the surrealist actors, but also involves the reader by means of documentary strategies. ${ }^{50}$

The concept of repetition and the participation of the recipient in the creative process manifest the permanent renewal of surrealist activity. ${ }^{51}$ Here, the creative appropriation of the game is not subject to the reproduction of the past but is characterized by a difference in content and form. ${ }^{52}$ The replay in its communicative element becomes a continuation of playing. In its renewed implementation, more and more components of the surrealist game emerge, which are not comprehensible in their whole.

The game project and the form of its documentation are characterized by an open structure. The constant interaction of production, action, and active appropriation by the viewer creates a constantly new work. ${ }^{53}$ In this context, the continuous expansion and transformation opens up the question of the "original" artistic work. ${ }^{54}$ Walter Benjamin, in his essay Das Kunstwerk im Zeitalter seiner technischen Reproduzierbarkeit (The Work of Art in the Age of Mechanical Reproduction, 1935), defines the element of authenticity as the central criterion of the original: "The here and now of the original makes up the concept of its authenticity. [...] The authenticity of a thing is the epitome of everything from its origin to what can be passed on, from its material duration to its historical testimony. ${ }^{155}$ Benjamin summarizes the characteristics under the term aura, which he denies to reproduced works of art. ${ }^{56}$ Because by "reproducing, reproduction takes the place of its unique occurrence in its masses."157

49 In this context, Švankmajer, the director of the game, also had a dual position.

50 EDER, Johanna Gundula. Homo Creans. Kreativität und Kreativitätsbildung im Kontext transmedialer Kunst. Bielefeld : transcript, 2016, p. 330.

51 SPIES, Werner. Der Surrealismus: Kanon einer Bewegung. Cologne : DuMont-Literatur-und-Kunst-Verlag, 2003, p. 97.

52 GELDMACHER 2015, p. 42.

53 EDER 2016, p. 38.

54 TIPPNER 2016, p. 150, 190.

55 "Das Hier und Jetzt des Originals macht den Begriff seiner Echtheit aus. [...] Die Echtheit einer Sache ist der Inbegriff alles von Ursprung her an ihr Tradierbaren, von ihrer materiellen Dauer bis zu ihrer geschichtlichen Zeugenschaft." See BENJAMIN, Walter. Das Kunstwerk im Zeitalter seiner technischen Reproduzierbarkeit. Frankfurt/Main : Suhrkamp, 1963, p. 12-13.

56 "... was im Zeitalter der technischen Reproduzierbarkeit des Kunstwerks verkümmert, das ist seine Aura" [“... what atrophies in the age of technical reproducibility of the work of art is its aura"]. See BENJAMIN 1963, p. 13.

57 “...die Reproduktion vervielfältigt, setzt sie an die Stelle seines einmaligen Vorkommens sein massenweises." See BENJAMIN 1963, p. 13. 
The Surrealist collective, on the other hand, understands the reproductive appropriation of artistic works as an independent creative process. The repetition of a work does not represent a copy of the original. In the process, the views and insights gained are examined, questioned, and restructured, leading to further possibilities of observation and perception. In the surrealist point of view, repetition does not express the identical, but rather the subjective and own - which is not only presented in the game but also seen in the transfer of individual works into the catalogue, which creates new content in their intermedial arrangement and form of reproduction. ${ }^{58}$

\section{Sphere of Dream - a medium of creative practice}

Reproduction as a creative and epistemological method is also evident in the structural implementation of the samizdat catalogues. The works presented in the volumes are not simply reconstructed, but staged using surrealist methods. In the specific form of creation as well as conception, the editions make the creative practice of the community and surrealist strategies accessible and tangible. The catalogue project itself becomes an artistic work and an expression of surrealist positions.

In the form of presentation, the community transforms its works into something new. It draws attention to the other by placing different projects into a common context. The reproduction does not repeat the apparent but makes the invisible visible in the accentuation. ${ }^{59}$ The catalogue becomes a stimulus for altered observation and opens up extended contexts of surrealist creativity. ${ }^{60}$

For the mediation, communication, and reception of surrealist practice, the community developed its own experimental strategies in the typography of the catalogue Sphere of Dream. Emotional, physical and psychological effects as well as stimuli were created through creative means. The organization of the elements established a "poetics of typography" 61 that reflected the programmatic and artistic guiding principles of surrealist activity.

By means of graphic design, the catalogue cover announces the dream phenomenon actively and creatively. In various font sizes and types, the project title Sféra snu is accompanied by several dream protocols in handwriting. Different written fonts are chosen to present the individual dream experiences. The handwriting expresses subjective characteristics which - like the experience of a dream - refer to the own self. In terms of extractability and legibility, the viewer can only perceive the written text in fragments, which cause confusion and mystery. The combination of the added drawings stimulates the reader's imagination. The decoding of the images and text segments triggers imaginative thoughts and associations,

58 HILMES, Carola. Auf der Suche nach dem surrealistischen Ich. Individualität und Wiederholung: Magritte und Breton. In HILMES, Carola - MATHY, Dietrich (ed.) Dasselbe noch einmal: Die Ästhetik der Wiederholung. Wiesbaden : VS Verlag für Sozialwissenschaften, 1998, p. 141.

59 GEIMER 2009, p. 89.

60 BOSSE 2004, p. 53.

61 See HULTSCH, Anne - RINCK, Julia. Zirkus in der Druckerei. Tschechische Avantgarde. Available online: http://www.collegium-carolinum.de/veranstaltungen/bohemisten-treffen/exposes-bohemisten-treffen/exposes2018.html 
through which non-receptive words are supplemented by the reader's own experiences. The surrealistic stories mix with personal stories and (dream) experiences. In the form of strategic design, the cover takes the viewer on an emotional journey into the world of dreams, which begins with turning the first page.

Intermediality is not only a documentary principle of communicating the content and formal elements of the contributions. In the combination of the works, the community develops a creative project that reflects the many-sided positions of surrealist practice in its medial diversity. This reveals the universality of expression, the interdisciplinarity of the group, and its broad understanding of art.

Collages, photographs, painting, and object art as well as analytical and poetic texts are equally important means of presenting surrealist work on the phenomenon of the dream. Their composition is not subject to any aesthetic or organizational restrictions, since the goal is to achieve the utmost artistic freedom of creation. ${ }^{62}$ Dryje determines in this respect: "From a Surrealist perspective this universality of expression ought to reflect an attempt at universality of thought. It ignores both genre and aesthetic aspirations, and yet in the spite of this - or because of it - it creates a new and unrepeatable context that allows unusually authentic and effective work to be produced." ${ }^{3}$ The dissolution of genre-specific characteristics and aesthetic criteria is connected with the attempt to break down the traditional, formal, medial, and structural boundaries of the arts as well as their genre affiliation and artistic categories in order to arrive at their own authentic expression. ${ }^{64}$ Nevertheless, in its autonomous expression, the community differentiates itself from abstract concepts of representation. Surrealist activity does not follow any preconceived formal order but leaves absolute freedom in the choice of means of articulation and external form. ${ }^{65}$

\section{An (active) mediation of surrealistic practice: The image-text references in the catalogue}

In the creative development, seemingly contradictory elements are combined, which lead to altered modes of representation. It is above all a picture-text reference that distinguishes surrealistic projects.

The linguistic-artistic works are based on the model of imagination and poetry. ${ }^{66}$ According to the surrealist understanding, the word productions are grounded on active elements, as the community explains: "Poetry is not cognition in the traditional, ordinary sense of the word. It is a more analogous, magical transformation

62 ROLOFF, Volker: Metamorphosen des Surrealismus in Spanien und Lateinamerika. Medienästhetische Aspekte. In ROLOFF, Volker - FELTEN, Uta (ed.). Spielformen der Intermedialität im spanischen und lateinamerikanischen Surrealismus. Bielefeld : transcript, 2015, p. 28.

63 See DRYJE, František. Formative Meetings. In ŠVANKMAJER, Jan (ed.) Evašvankmajerjan: Anima Animus Animation, Between Film and Free Expression. Prague : Arbor vitae, 1997, p. 12.

64 ROLOFF, Volker. Einleitung. In ROLOFF, Volker - RIßLER-PIPKA, Nanette - QUEIPO MAURER, Isabel (ed.) Die grausamen Spiele des »Minotaure«. Bielefeld : transcript, 2015, p. 7.

65 This can be seen not least in the surrealistic games of the community, in which free choice of means of expression is allowed in the design of the creative answers to the questions asked. EFFENBERGER, Vratislav. Variants, Constants and Dominants of Surrealism. In Analogon. Surrealismus - Psychoanalýza - Antropologie - Příčné Vědy. Z dějin československého surrealismu 1968-1989, 2004, No. 41/42, p. iii.

66 TIPPNER 2016, p. 148. 


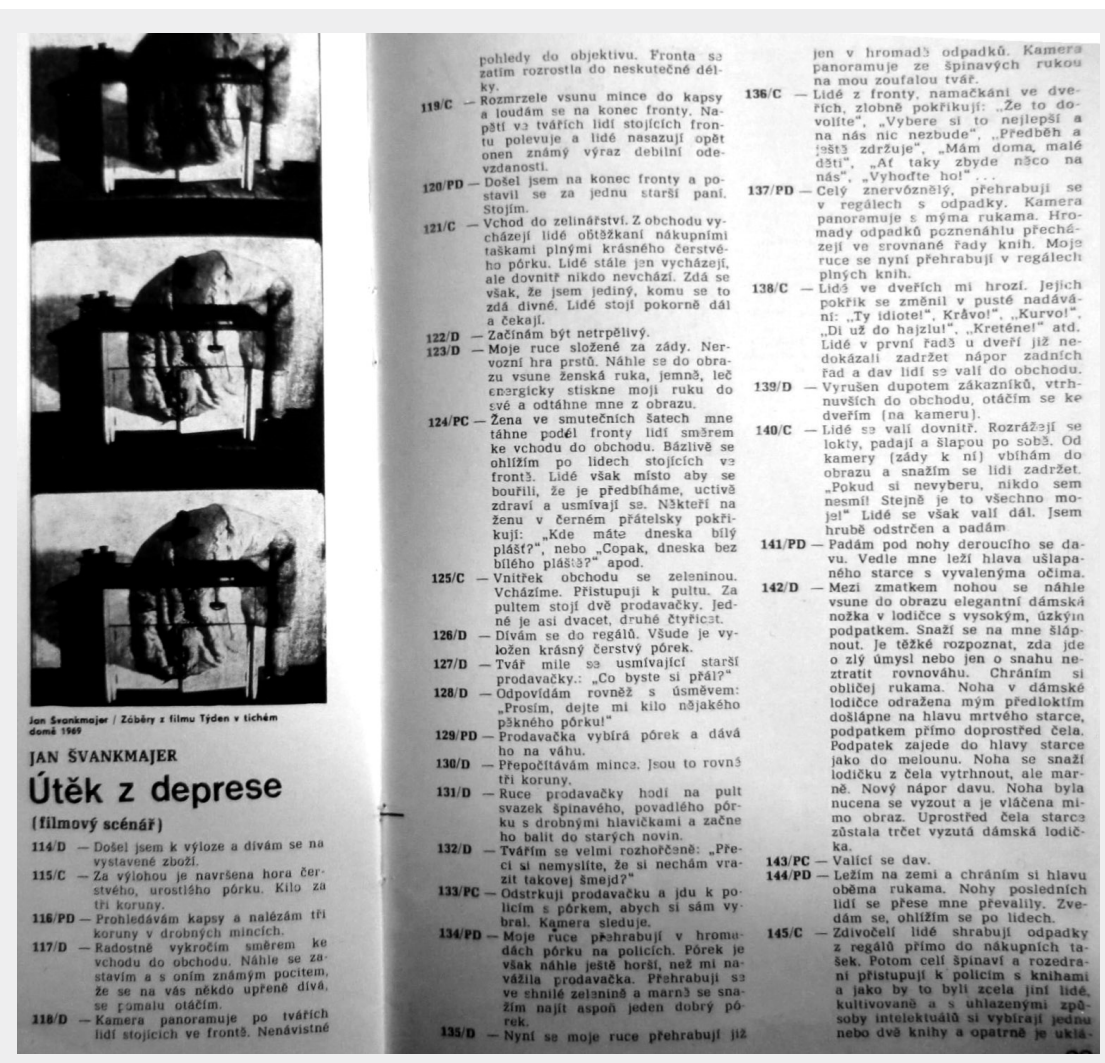

Figure 11: J. Švankmajer: Útěk z deprese (Escape from Depression)/ film script In: Surrealistická skupina v Československu (ed.): Sféra snu (Sphere of Dreams). 1983, p. 28/ 29. Source: By the kind permission of the Archiv Libri Prohibti (Prague) and metamorphosis; it releases from the depths of the unconscious a kind of mental catalyst, the action of which amplifies and strengthens the whole complex of consciousness." ${ }^{\prime 67}$ The source of surrealistic poetic texts are their own sensations and subjective images, which are expressed in the unconscious. Thereby it is the imagination that leads all creative processes. It creates mental pictures and pro-

vokes associations that find material expression in the texts. Thus, writings reflect and transform personal thoughts into words and language of different forms, such as poems, essays, and autobiographical tracts. Thereby visual elements blur in textual contributions and vice versa.

Švankmajer's film script Útěk $z$ deprese (Escape from Depression) in Sphere of Dream is presented in fragments and describes a shopping scene: The first-person narrator enters a store with the intention of buying leeks, which at the moment of selection turns into garbage and then into books (picture 11). ${ }^{68}$

Švankmajer's contribution is based on dreams of different nights, which he brings together in his screenplay as an imaginative cycle. His dreamy experiences deal with personal moments and play with emotions like shame and excitement: 69 "135/close up - My hands go through piles of nothing but trash. The camera pans from the dirty hands to my desperate face. 137/half detail - I'm all nervous

67 "Poesie není poznáním v tradičním, běžném slova smyslu. Je více analogickou, magickou transformací a metamorfosou; uvolňuje z hlubin nevědomí jakýsi mentální katalysátor, jehož pưsobením se umocňuje a zesiluje celý komplex vědomí." See SURREALISTICKÁ SKUPINA V ČESKOSLOVENSKU. Nalezené vědomí. In ŠVANKMAJER, Jan - KOUBEK, Jiří (ed.). Opak zrcadla. Surrealistická poesie. Antologie tvorby Surrealistické skupiny v Československu 1980-1985. Geneva (Prague) : Le La, 1979, p. 7.

68 ŠVANKMAJER, Jan. Útěk z deprese. In Sféra snu. Geneva (Prague) : Le La, 1983, pp. 28-30.

69 The script includes other dreamy scenes reflecting experiences of his childhood and thoughts on his work, including a meeting of the surrealist community with André Breton, where Švankmajer presents his game Restaurátor. The excerpts are not shown in Sphere of Dream. SCHMITT, Bertrand. Detailed biography with commentary (II) 1971-1989. In DRYJE, František - SCHMITT, Bertrand (ed.). Jan Švankmajer. Dimensions of Dialogue. Between Film and Fine Art. Prague : Arbor Vitae, 2013, p. 145. 
and always going through the shelves with the garbage. The camera pans to my hands. The piles of garbage suddenly turn into orderly rows of books. My hands are now going through the shelves full of book." ${ }^{\prime \prime 0}$ According to the dream protocols, the passages are based on mental images, which are transformed into written scenes in their reflection. Escape from Depression materializes

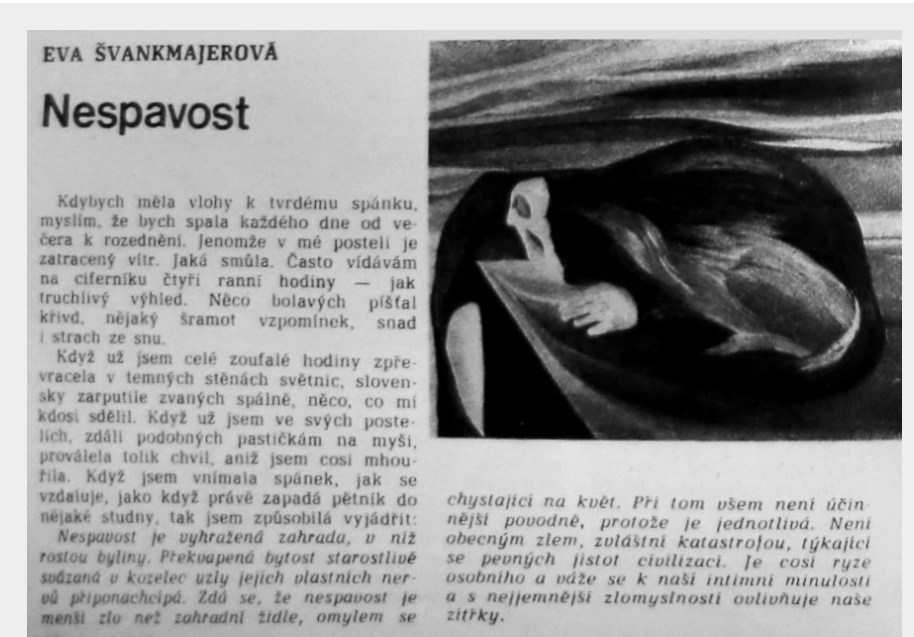

Figure 12: E. Švankmajerová: Nespavost (Insomnia)/ painting In: Surrealistická skupina v Československu (ed.): Sféra snu (Sphere of Dreams). 1983, p.10.

Source: By the kind permission of the Archiv Libri Prohibti (Prague) the unconscious and poetic processes of the author. However, the film project does not aim at the technical realization but rather tries to convey fictional images and create further ones in its appropriation. ${ }^{71}$

By transforming his dreamy experiences into an imaginative script, Švankmajer plays with commonalities between film and the phenomenon of dream, which Dryje presents in his treatise sen a film (dream and film, 1981). Dreams, like a film, appear as a performance that makes time and space, independent of reality, tangible in an imaginative way. In his leading role the spectator meets imaginary characters and objects and experiences a number of different states. A film, which reproduces an apparent external reality, possesses the mysterious ability to stimulate psychological processes and create inner images - just like the process of dreaming. ${ }^{72}$

Conversely, the artistic contributions are also characterized by narrative elements. The painted work Nespavost (Insomnia) by Švankmajerová depicts an imaginative creature in the shape of a mouse with grotesquely frightening human features. ${ }^{73}$ The mysterious creature appears in its ghostly form with empty eyes as a threat on a pedestal - the danger of dreams.

Švankmajerová complements the picture by describing the negative experience of insomnia at night, which she calls desperate hours (zoufalé hodiny): "Bad luck. I often see four o'clock on the dial - what a sad view. [...] When I am in my bed, which is like mousetraps, I have gone through so many moments without

70 „135/D - Nyní se moje ruce přehrabují již jen v hromadě odpadků. Kamera panoramuje ze špinavých rukou na mou zoufalou tváŕ. [...] 137/PD - Celý znervóznělý, přehrabují se v regálech s odpadky. Kamera panoramuje s mýma rukama. Hromady odpadkủ poznenáhlu precházejí ve srovnané ŕady knih. Moje ruce se nyní prehrabují v regálech plných knih." See ŠVANKMAJER 1983, p. 29.

71 OWEN, Jonathan. Films for the Drawer: Postwar Czech Surrealism and the Impossible Encounter with Cinema. In FERREBOEUF, Rebecca - NOBLE, Fiona - PLUNKETT, Tara (ed.) Preservation, Radicalism, and the Avant-Garde Canon. New York : Palgrave Macmillan US, 2016, p. 243.

72 In the psychoanalytical sense, film and dreams can unconsciously influence different levels of human behaviour and psyche, where the principle of reality becomes the pleasure principle. DRYJE, František. sen a film. In Sféra snu. Geneva (Prague) : Le La, 1983, p. 27.

73 ŠVANKMAJEROVÁ, Eva. Nespavost. In Sféra snu. Geneva (Prague) : Le La, 1983, p. 10. 
blinking." ${ }^{\prime \prime 4}$ The contribution Insomnia transforms the narrative sensations into a surrealistic visual language. The words become images and tell a personal story: The bed - the mousetrap - appears as a place of imprisonment, which terrifies the own ego in the form of the mouse, and the symbol of insomnia is a ghostly and frightening human experience which manifests itself in the expression of a face. This is a view into the abyss, into which one is torn by sleep deprivation. Švankmajerová's visual work plays with imagination and its own experiences in its realization: "I do, however, know very precisely that at times when I could hardly sleep at all, pictures used to bounce into my mind. Blinks. Condensed spasmodic reports or visions. As if I was sleeping dreaming." ${ }^{75}$ The work Insomnia appears as a visual analogy of inner processes. The term "insomnia" becomes a poetic image that is far from logical explanations and rational interpretations. It is based as Švankmajerová emphasizes - on personal experience and unfolds its magical meaning through imaginative associations and illusory transformation.

The inseparable interconnection of image and text becomes an autonomous creative element. As a consequence, new forms of expression and artistic genres emerge, which require changed patterns of perception and reception. ${ }^{76}$ The reflective appropriation of the works plays with conventional reading and viewing habits and causes dissolution of classical genres.

Surrealistic pictorial works are not only seen, but read. The creative works thus extend the traditionally ascribed visual form of appropriation of pictorial works by means of media combination and permanent reference by a further level of sensory experience. Nevertheless, the transformation of written sources into visual material shifts the process of reading to the act of seeing.

The multi-layered references require a constant alternation between reading and seeing in order to open up encoded contents in the objects and texts. They challenge the viewer by interrupting rational linear reading experiences and seemingly logical forms of reception.

In the mediation of surrealistic contributions, the community makes various forms of received reading available. Reading is not only a passive act; it also unfolds creative elements. Švankmajer's imaginary script creates poetic scenes that create images and convey emotions. In the detailed description of individual passages and the recording of concrete camera angles, the script becomes an imaginative film guide. The dreamy segments do not communicate real moments. They stimulate the reader's imaginative vision by linking everyday experiences such as shopping - with fictional events. In combination with captured feelings

74 "Jaká smůla. Často vídávám na ciferníku čtyři ranní hodiny - jak truchlivý výhled. [...] Když už jsem ve svých postelích, zdáli podobných pastičkám na myši, proválela tolik chvil, aniž jsem cosi mhouřila." See ŠVANKMAJEROVÁ 1983, p. 10.

75 See SVANKMAJEROVÁ, Eva. In ŠVANKMAJER, Jan (ed.) Evašvankmajerjan: Anima Animus Animation, Between Film and Free Expression. Prague : Arbor vitae, 1997, p. 136.

76 LOMMEL, Michael - ROLOFF, Volker - SCHUHEN, Gregor. Intermedialität im europäischen Surrealismus. In SPIEL (Siegener Periodicum für internationale empirische Literaturwissenschaft), 2001, No. 20 (2), p. 246. 
("I'm all nervous..."), they evoke associations that provoke familiar sensations in the recipient. In the concept of imagination, the film is realized in the mind's eye of the reader and unfolds its artistic potential. ${ }^{77}$ The representation in the fragments stimulates the thoughts of the viewer, who can continue or end the film in his or her personal imagination. Reading is thus not only an active experience, but it also makes the spectators an extended component of surrealistic practice through their own inspiration.

In the mental realization of the film, the communication of surrealist theory is at the same time evident. The script - between dream protocol and film - puts Dryje's analytical description dream and film into practice by means of an imaginary performance. Thus, in Sphere of Dream, not only theoretical processes are presented, but can be experienced and verified in artistic appropriation.

In the coherence of image and text, seeing and reading as part of the creative and theoretical programme, the surrealist community creates a specific form of art mediation. Sphere of Dream is linked to the concept of the implied reader, which in the presentation of the contributions takes into account the construct of effect and the perception of the recipient. In the principle of repetition and the model of the imagination, the unrepresented - such as the film Escape from Depression - is presented in the consciousness of the reader. ${ }^{78}$ Reading is declared a dynamic process that triggers interactions and communication structures between author, work, and reader. ${ }^{79}$ At the same time, a liberating force is ascribed to reading. In the reflection of the works, the group stimulates unconscious processes, which in the practical implementation unfold a consciousnesscreating and psychological effect. The knowledge gained leads to a modification of perception, which allows a different view of the environment.

\section{Sphere of Dream - exhibition catalogue or exhibition?}

In its (interactive) characteristics, the catalogue appears as the projection of an ideal exhibition format. The surrealistic "book" becomes a space of experience that puts the viewer in a position to receive, touch, and create art.

In his essay The New Art of Making Books (1975), the artist Ulises Carrión defines a book as a sequence of spaces:80 "What a book is. A book is a sequence of spaces. Each of these spaces is perceived at a different moment - a book is also a sequence of moments. [...] A book is a space-time sequence."181 In accordance with Carrión's conception, Sphere of Dream forms three thematic (exhibition) sequences in its

77 In times of political repression, however, this imaginative strategy shows itself to be a possibility for realizing the film. Švankmajer was banned from working as a filmmaker in the 1970s.

78 "Das Konzept des impliziten Lesers umschreibt daher einen Übertragungsvorgang, durch den sich die Textstrukturen über die Vorstellungsakte in den Erfahrungshaushalt des Lesers übersetzen." ["The concept of implied reader therefore describes a transfer process through which text structures are translated via the act of representation into the reader's experience balance.']. See ISER, Wolfgang. Der Akt des Lesens: Theorie ästhetischer Wirkung. Munich : UTB, 1976, p. 67.

79 ISER 1976, p. 176.

80 DEINERT, Katja. Künstlerbücher. Historische, systematische und didaktische Aspekte. Hamburg:

Dr. Kovač, 1995, p. 210.

81 See CARRIÓN, Ulises. Second Thoughts. Amsterdam : VOID distributors, 1980, pp. 7-8. 
classification: I/ Between Sleep and Waking (p. 4-10); II/ Through Inner Vision (p. 11-19), III/ Night Visits (p. 20-32). The recipient becomes a visitor who walks through the rooms. He can pass the works by turning the pages; he can stand still and experience the work by reading and seeing, and interact with the work by repeating it. The temporal component is realized by leafing through the works in the sense of the duration of an exhibition visit.

The production of the catalogue reflects its organizational elements: in the design, the community assumes the function of curator, who decides on the selection of works and their hanging. At the same time, it holds the position of the exhibiting artist, who makes his or her works available. ${ }^{82}$ The surrealistic samizdat catalogue reflects the idea of a portable museum. ${ }^{83}$ This museum concept expresses the intention to create a mobile exhibition project. ${ }^{84}$ In its implementation, the self-published volume of the community follows the tradition of surrealist exhibition staging. The catalogue presents itself as a world of experience in its own way. ${ }^{85}$

The group conceives its installation as a "social" event, not as a passive act of observation. ${ }^{86}$ It does not simply present surrealist works but stages a space for specific perception, experience, and emotion. They understand their exhibition as an active experience that challenges and provokes the "visitor" through his or her senses, while at the same time providing creative and theoretical guidelines. Their modes of representation play with the confusion of the recipient and ascribe to him a central role in the realization of their contributions. Through imaginative stimulation, the viewer can watch films and participate in a playful performance. He can interactively experience the medial diversity and universality of creation.

The community project takes the format of the exhibition out of the gallery space or museum and transforms it into a mobile (book) form. The group shows that art does not receive its creative value because it staged in a gallery or is present in a museum. It does not acquire its significance in the local context, but rather in the reflection of individual creative impulses independent of spatial conditions. In passing on the samizdat, any place can become a place of experiencing art. No specific institution is required for this.

82 The catalogue points out parallels to the exhibition practice of the community since its foundation. As a tendency, all organizational tasks for the installation remain within the group.

83 In addition, the surrealist catalogue shows parallels to the idea of the Musée Imaginaire by André Malraux (1947). In his paper, Malraux contrasts the reproduction of art in the context of the museum and the illustrated book. It is not about technical criteria (Walter Benjamin), but rather about the form of archiving and the contextualization of art. Malraux discusses photographic reproduction in this context. Despite the overlap in the concept of the surrealist catalogue in Malraux's explanations, due to the diversity of media - from commentary to theoretical treatises to games - only a reference can be made at this point. For more, see: MALRAUX, André. Le musée imaginaire. Paris : Gallimard, 1996. GEIMER 2009, p. 80.

84 Marcel Duchamp created an early precursor with La Boîte-en-valise, which contains reproductions and objects such as photographs.

85 Numerous surrealist exhibitions are staged as experiences, including the exhibition Princip Slasti (Pleasure Principle, Prague, Bratislava, Brno 1968).

86 TIPPNER 2016, p. 59. 
In this context, the catalogue as a surrealist strategy questions the principle of the exhibition as an act of displaying material works. Through a change of media, the community presents its works in their physical absence. Nevertheless, the images and texts in their reproductions are not to be understood as simple copies. They create something new, which in its conceptual mediation makes the surrealist guidelines accessible. The communication of the creative practice is not tied to a concrete object, material, or a certain form. ${ }^{87}$ The community designs an exhibition without art and points out that the reception of art is a form of open dynamic thinking and not the contemplation of an aestheticized artefact. ${ }^{88}$

\section{The surrealist concept: the samizdat catalogues and their functions}

The complex formal, content-related, and conceptual references assign different positions to the samizdat catalogues. In the selection, compilation, and presentation of the works, the self-published projects appear as a self-archiving medium. The community adopts the principles of collecting, preserving, and researching. It systematizes its practice in a context and makes it accessible. In the process, a surrealist archive, which is a place of encounter, communication, and creation as well as a repository and producer of knowledge, is created.

In its structural implementation it determines the form of interpretation and the reception of art. The community makes use of documentary methods of arrangement and intermediality, which not only convey concrete content, but also surrealistic creative premises. The recipient not only determines these in terms of content but also actively experiences them. At the same time, the group-internal selection of the material and the form of its presentation generate subjective views of the theme. ${ }^{89}$ The catalogue communicates its own view on everyday phenomena and thus the perception of the environment and the world..$^{90}$ The strategy of archiving is shown in this context as a process that creates its own realities through self-reflection.

In the reappraisal of surrealist practice, the catalogue nevertheless shows itself to be the result of collective action. It is the result of joint reflection, action, and creation - from individual contributions to a collection of works, from the idea of the design and the concept to material implementation. It is only through the interplay of the individual elements that the surrealist project, whose concept reflects a specific conception of art, emerges. Artistic creation is understood as a dynamic process of permanent renewal which is not bound to material and media forms of expression.

In its multi-layered references, the community's catalogue projects refer to different constructions of meaning. In times when there is no public reception of the collective surrealist creation in museums, institutions, and the scientific commu-

87 Only the catalogue can be seen as a material work in its collective production.

88 Without Art understands art in terms of its representational nature.

89 This also includes, for example, the capture in the fragment.

90 DEINERT 1995, p. 209. 
nity, the group itself provides a remedy by presenting and reappraising its own view of Czech surrealism and group history. They make their activities visible and permanently accessible, and this takes place within a closed framework. They record and document ephemeral actions and presents them in their ideal exhibitions. At the same time, the community designs a creative object that reflects the guidelines of its practice. The internal self-publishing becomes a symbol of surrealistic diversity that cannot be reduced to a moment of meaning.

\section{Acknowledgements}

I would like to thank Schroubek Fonds Eastern Europa for the Leopold Kretzenbacher Scholarship as well as the Academy of Sciences Czech Republic for the Josef Dobrovský Fellowship, both of which supported the research on samizdat and enabled the writing of the article. Furthermore, I would like to thank my colleagues from the Institute of Czech Literature AV ČR, who contributed to the project by providing advice regarding the material. Special thanks are also addressed to Jiř́ Gruntorád and Jiří Něnička of the Libri Prohibiti Library for their assistance and for providing sources and permission for publication. Last but not least, I would also like to thank my supervisor, Prof. Dr. Martin Schieder (University of Leipzig), and my co-supervisor, Prof. Dr. Alfrun Kliems (Humboldt University Berlin), for supporting my PhD project on Czech Surrealism.

Cite:

Watterott, Kristin. Self-publishing as a Surrealist Strategy: The Samizdat Catalogues of the Surrealist Group in Czechoslovakia. In Forum Historiae, 2020, Vol. 14, No. 2, s. 14-35. ISSN 1337-6861. DOI: https://doi.org/10.31577/forhist.2020.14.2.2

Kristin Watterott, M.A. Institut für Kunstgeschichte

Fakultät für Geschichte, Kunst und Orientwissenschaften

Universität Leipzig

Dittrichring 18-20, 04109 Leipzig

Germany

E-mail:watterott@gmx.de 